\title{
ABUNDANCE OF COCCOID CYANOBACTERIA, HYDROGRAPHIC PARAMETERS AND THE POSSIBLE UNDERESTIMATION OF IN SITU CHLOROPHYLL $a$ IN THE NORTHERN GULF OF CALIFORNIA AND THE MEXICAN CALIFORNIA CURRENT
}

\section{ABUNDANCIA DE CIANOBACTERIAS COCALES, PARÁMETROS HIDROGRÁFICOS Y LA POSIBLE SUBESTIMACIÓN DE LA CLOROFILA $a$ IN SITU EN EL NORTE DEL GOLFO DE CALIFORNIA Y LA CORRIENTE DE CALIFORNIA, MÉXICO}

\author{
Cecilia Díaz \\ Helmut Maske* \\ División de Oceanología \\ Centro de Investigación Científica y de Educación Superior de Ensenada \\ Apartado postal 2732 \\ Ensenada, C.P. 22880, Baja California, México \\ *E-mail: hmaske@cicese.mx
}

Recibido en mayo de 1999; aceptado en junio de 2000

\begin{abstract}
The abundance of coccoid cyanobacteria was counted within the euphotic zone at a station in Delfín Basin, in the northern Gulf of California, and at a station in the California Current, off Todos Santos Bay, during 1993. The abundance of cyanobacteria at both stations was between $10^{7}$ and $10^{8}$ cells $\mathrm{L}^{-1}$. Comparison with other concomitantly sampled parameters, i.e., irradiance, temperature, nutrients and chlorophyll $a$, showed no significant correlation with the cyanobacterial abundance. The contribution of cyanobacteria to the total in situ chlorophyll a concentration was calculated using the cyanobacterial abundance, an average published value of $1.0 \mathrm{fgChl} a \mathrm{cell}^{-1}$ and a reduced pigment extraction efficiency in cyanobacteria. Cyanobacteria contributed, in half of the cases, more than $10 \%$ and more than $4 \%$ of the total chlorophyll in Delfín Basin and the California Current, respectively. Again, this relative contribution was not related to the other concomitantly measured in situ parameters. In Synechococcus (WH-7803) cultures, the cellular chlorophyll $a$ concentration was measured after extraction by soaking the samples in different solvents: $90 \%$ acetone and dimethylsulfoxide/acetone/water (DMSO/acetone). The cellular chlorophyll of WH-7803 extracted with DMSO/acetone was a factor of 1.9 times higher than the cellular chlorophyll concentration extracted with $90 \%$ acetone without sonication. Assuming that only the cyanobacteria would yield higher chlorophyll concentrations with DMSO/acetone extraction, then the chlorophyll $a$ concentrations measured with $90 \%$ acetone extraction without sonication underestimated, in half of the cases, the real concentrations of in situ chlorophyll $a$ by more than $5 \%$ in the northern Gulf of California and more than $2 \%$ in the California Current.
\end{abstract}

Key words: picoplankton, chlorophyll $a$, nutrients, Gulf of California, California Current. 
Ciencias Marinas, Vol. 26, No. 3, 2000

\section{RESUMEN}

La abundancia de cianobacterias cocales en la zona eufótica en una localidad ubicada dentro de la Cuenca Delfín, en el norte del Golfo de California, y otra ubicada en la Corriente de California, hacia la Bahía de Todos Santos (México), fue de $10^{7}$ a $10^{8}$ cél $\mathrm{L}^{-1}$ durante algunos meses de 1993. Su comparación con los parámetros de muestreo de irradiancia, temperatura, nutrientes y clorofila $a$ no muestra una correlación significativa con la abundancia de cianobacterias. Se calculó la contribución de las cianobacterias a la concentración in situ de clorofila $a$ empleando un valor promedio de la concentración celular de clorofila $a$ en cultivos de Synechococcus obtenido de la literatura (1.0 fg Chl $a$ cél $^{1}$ ), una reducida eficiencia de extracción de clorofila $a$ y la abundancia de cianobacterias cocales in situ. La contribución de las cianobacterias, en la mitad de los casos, para la Cuenca Delfín fue arriba de 10\% y para la Corriente de California, arriba de $4 \%$ del total de la clorofila $a$. La contribución relativa no muestra relación con los parámetros ambientales. Se realizaron mediciones de la concentración de clorofila celular en Synechococcus (WH-7803) empleando, para su extracción sin tratamiento físico por diferentes solventes, acetona al 90\% y dimetil sulfóxido/acetona/agua (DMSO/acetona). La concentración de clorofila celular en WH-7803 extraída con DMSO/acetona fue un factor de 1.9 veces más alto que la concentración de clorofila extraída con acetona al 90\%. Suponiendo que solamente las cianobacterias pueden alcanzar altas concentraciones de clorofila en la extracción con DMSO/acetona, entonces las concentraciones de clorofila $a$ medidas en la extracción con acetona al $90 \%$ subestimaron las concentraciones reales in situ de la clorofila $a$, en la mitad de los casos, en más de $5 \%$ en el norte del Golfo de California y más de $2 \%$ en la Corriente de California.

Palabras clave: picoplancton, clorofila $a$, nutrientes, Golfo de California, Corriente de California.

\section{INTRODUCTION}

In the oceans, phytoplankton smaller than $2 \mu \mathrm{m}$, autotrophic picoplankton consisting mainly of coccoid cyanobacteria, Synechococcus spp. and Prochlorococcus, form a significant part of the phytoplankton biomass (e.g., Li, 1998). Autotrophic picoplancton could only be studied after the relatively recent development of epifluorescent microscopy and flow-cytometers, and this is one of the reasons why there are no published studies of coccoid cyanobacteria from Mexican Pacific waters or the Gulf of California. The information available for other areas, including the California Current, shows that cyanobacteria are ubiquitous and can play an important part in the ecology of the oceanic pelagial as particulate carbon and as primary producers (Iturriaga and Mitchell, 1986). So far, no explanation has been published as to

\section{INTRODUCCCIÓN}

El fitoplancton pequeño, menor que $2 \mu \mathrm{m}$, picoplancton autotrófico constituido principalmente por las cianobacterias cocales, Synechococcus spp. y Prochlorococcus, representan una parte significativa de la biomasa del fitoplancton (e.g., Li, 1998). El picoplancton autotrófico pudo estudiarse gracias al reciente desarrollo de la microscopía epifluorescente y citometría de flujo, razón por la cual no existen estudios publicados de las cianobacterias cocales en aguas del Pacífico mexicano y Golfo de California. La información publicada de otras áreas, incluyendo la Corriente de California, muestra que las cianobacterias se encuentran universalmente distribuidas como parte ecológica importante del océano pelágico, así como del carbono particulado y los productores primarios (Iturriaga y Mitchell, 1986). No obstante, no existe una explicación 
why cyanobacteria contribute variable amounts of biomass to the phytoplankton, and no relation has been found between the relative contribution of coccoid cyanobacteria and in situ irradiance, temperature or nutrients (Wyman et al., 1985; Smith, 1986; Vernet et al., 1990). Oceanic coccoid cyanobacteria, such as Synechococcus spp., are not molecular nitrogen reducers and therefore do not possess a selective advantage under conditions of nitrogen limitation.

It has been suggested that cyanobacteria are chromatically well adapted to the deeper part of the euphotic zone because of the green absorption bands (approximately $555 \mathrm{~nm}$ ) of the photosynthetic pigment phycoerythrin (PE) (Ikeya et al., 1994), but this hypothesis has not been substantiated in the literature. The different strains of Synechococcus have been found to contain variable amounts of phycourobiliproteins (PUP), with absorption maxima around 500nm. Further away from the coast, where the irradiance in the deeper part of the euphotic zone would have shorter wavelength, the Synchecococcus strains with more PUP are more dominant (Wood et al., 1998). Again, this has been suggested as a phytochromatic adaptation, but so far the possibility of coincidental trends cannot be excluded. The culture strain WH-7803 is a good model of a PUP containing offshore Synechococcus. Here, WH-7803 was used to test the extraction efficiency of chlorophyll with different organic solvents and then to calculate the relative contribution of coccoid cyanobacteria to the in situ chlorophyll concentration.

\section{MATERIAL AND METHODS}

The station in Delfín Basin is located on the western side of the basin $\left(30^{\circ} 13^{\prime} \mathrm{N}\right.$, $\left.114^{\circ} 15^{\prime} \mathrm{W}\right)$, at a depth of $200 \mathrm{~m}$. Delfín Basin is the deepest basin in the northern Gulf of California. Delfín Basin was sampled on five del por qué las cianobacterias hacen una contribución variable a la biomasa de fitoplancton, y no se ha encontrado una relación entre la concentración relativa de las cianobacterias cocales con la irradiancia in situ, temperatura y nutrientes (Wyman et al., 1985; Smith, 1986; Vernet et al., 1990). Las cianobacterias cocales oceánicas, como Synechococcus, no pueden reducir el nitrógeno molecular y no tienen una ventaja selectiva bajo condiciones de limitación por nitrógeno.

Se ha sugerido que las cianobacterias están cromáticamente bien adaptadas en las partes bajas de la zona eufótica, debido a la absorción de luz en la región verde del espectro visible por su pigmento fotosintético ficoeritrina (PE), aproximadamente a $555 \mathrm{~nm}$ (Ikeya et al., 1994). No obstante, dicha hipótesis no ha sido bien fundamentada en la literatura. En las diferentes familias de Synechococcus se ha encontrado que contienen cantidades variables de ficourobiliproteínas (PUP), con una máxima absorción alrededor de los $500 \mathrm{~nm}$. Lejos de la costa, en la parte profunda de la zona eufótica donde predominan las longitudes de onda corta de la irradiancia, las familias de Synechococcus con PUP son las más dominantes (Wood et al., 1998). Esto ha sido sugerido como una adaptación cromática, pero no se puede negar la posibilidad de la covariación. Los cultivos de la familia WH-7803 constituyen un buen modelo de una cepa oceánica de Synechococcus con PUP. En este estudio se usó Synechococcus WH-7803 para probar la eficiencia de extracción de la clorofila con diferentes solventes orgánicos y se calculó la contribución relativa de cianobacterias cocales a la concentración de clorofila in situ.

\section{MATERIALES Y MÉTODOS}

La estación en la Cuenca Delfín se localiza hacia el lado oeste de la cuenca $\left(30^{\circ} 13^{\prime} \mathrm{N}\right.$, $114^{\circ} 15^{\prime} \mathrm{W}$ ), a una profundidad aproximada de 
Ciencias Marinas, Vol. 26, No. 3, 2000

days between July 1993 and December 1994. The station in the California Current is located off Todos Santos Bay ( $\left.31^{\circ} 50^{\prime} \mathrm{N}, 116^{\circ} 53^{\prime} \mathrm{W}\right)$, at approximately $500 \mathrm{~m}$ depth. The California Current station was sampled on seven days between May 1993 and January 1994.

At the stations, the hydrographic parameters were profiled with a CTD (Seacat, Seabird) and an optical profiler (PNF, Biospherical) that measured upwelling radiance for the estimation of natural fluorescence (García-Mendoza and Maske, 1996) and scalar irradiance of photosynthetic active radiation (PAR). Water samples were collected with a 5-L Niskin bottle at light depths of $100 \%, 33 \%, 10 \%, 3.3 \%$ and $1 \%$ $\left(E_{s}\right)$. The light depths were calculated from the Secchi depth solving $E_{z}=E_{s} e^{k z}$ for $z$, where $z$ is the depth in meters, $E$ is the relative irradiance (surface $=100$ ) and $k$ was calculated from the Secchi depth (sd), by $k=1.7 /$ sd. Below we report the true light depth calculated from the scalar irradiance measurements.

For the cyanobacterial counts, water samples of 30-60 mL were fixed with glutaraldehyde at a final concentration of $1 \%$ (Booth, 1987). Samples were filtered on $25 \mathrm{~mm}$ aluminum oxide filters (Anodisc, Whatman), with $0.2 \mu \mathrm{m}$ pore size at a differential pressure of $20 \mathrm{mPascal}$. The filters were mounted on microscope slides with a drop of immersion oil (Cargille, DF), covered with cover slips, sealed with nail polish and stored at $-20^{\circ} \mathrm{C}$. Cyanobacteria were counted with an epifluorescent microscope (Jenalumar, Zeiss) with a $\mathrm{Hg}$ lampof $50 \mathrm{~W}$ and an immersion objective of $100 \times$. For the excitation side an interference filter of $480 \pm 5 \mathrm{~nm}$ (Melles-Griot) was used; the dichroic filter had a cut-off wavelength of $570 \mathrm{~nm}$ and on the emission side, a color glass filter with a transmittance band above $580 \mathrm{~nm}$ was used. From 200 to 300 cells were counted per sample. Using the square root estimate of the standard deviation, the minimum coefficient of variation was calculated to be $6-7 \%$.
200 m. La Cuenca Delfín es la más profunda de las cuencas localizadas en la parte norte del Golfo de California. En esta estación se realizaron cinco muestreos mensuales comprendidos entre los meses de julio y diciembre de 1993. La estación en la Corriente de California se localiza hacia la Bahía de Todos Santos ( $\left.31^{\circ} 50^{\prime} \mathrm{N}, 116^{\circ} 53^{\prime} \mathrm{W}\right)$, a una profundidad aproximada de $500 \mathrm{~m}$. Aquí se realizaron siete muestreos mensuales comprendidos entre los meses de mayo de 1993 y enero de 1994.

En ambas estaciones, los perfiles hidrográficos se realizaron con un CTD (Seacat, Seabird). Las mediciones de irradiancia escalar fotosintéticamente activa (PAR) y fluorescencia natural se efectuaron con un perfilador óptico (PNF, Biospherical) (García-Mendoza y Maske, 1995). Las muestras fueron recolectadas con botellas Niskin de $5 \mathrm{~L}$ de capacidad con ligas y empaques de silicón, a las profundidades ópticas de $100 \%, 33 \%, 10 \%, 3.3 \%$ y $1 \%$ de la irradiancia $\left(E_{s}\right)$. Las profundidades de luz se calcularon partiendo de la profundidad del disco de Secchi en metros ( ), mediante la ecuación $E_{z}=E_{s} e^{k z}$, donde $E$ es la irradiancia en la superficie $(=100)$ y $k$ se calculó de la profundidad del disco de Secchi (sd), mediante $k=1.7 /$ sd. En los resultados se reporta la profundidad de luz real obtenida de las mediciones de PAR.

Para el conteo de cianobacterias, las muestras de 30-60 mL se fijaron adicionando glutaraldehído a una concentración final de $1 \%$ (Booth, 1987). Las muestras fueron filtradas por filtros de óxido de aluminio (Anodisc, Whatman) de $25 \mathrm{~mm}$ de diámetro y $0.2 \mu \mathrm{m}$ de tamaño de poro, a una presión diferencial de $20 \mathrm{mPascal}$. Los filtros fueron montados en portaobjetos con adición de una gota de aceite de inmersión (Cargille, DF) antes de colocar el cubreobjetos; posteriormente, se almacenaron a $-20^{\circ} \mathrm{C}$. Se contaron las cianobacterias en un microscopio de epifluorescencia (Jenalumar, 
Díaz and Maske: Picoplankton contribution to chlorophyll

The hydrographic parameters, nutrients, chlorophyll concentrations and primary production are reported in Cervantes et al. (1996). The nutrients, $\mathrm{NO}_{2}, \mathrm{NO}_{3}, \mathrm{Si}(\mathrm{OH})_{4}$ and $\mathrm{PO}_{4}{ }^{3}$, were measured with a segmented flow autoanalyser (Technicon), according to Whitledge et al. (1986, technical report). The in situ chlorophyll concentration was measured spectrophotometrically after extraction at $4^{\circ} \mathrm{C}$ for 24 hours with $100 \%$ acetone, adding $10 \%$ of water one hour before the measurement and using the specific absorption coefficients of Jeffrey and Humphrey (1975). Primary production was measured with the ${ }^{14} \mathrm{C}$ method using in situ incubation (García-Mendoza and Maske, 1996).

Synechococcus (WH-7803) chlorophyll a was extracted by soaking the samples at $4^{\circ} \mathrm{C}$ without physical treatment in different solvents: acetone, acetone + water at $0.9+0.1$ (90\% acetone), dimethyl sulfoxide (DMSO), and DMSO + acetone + water at $0.4+0.55+$ 0.05 (DMSO/acetone). Here we report only the results obtained with the standard solvent $90 \%$ acetone and with the most efficient solvent DMSO/acetone. In 90\% acetone and DMSO/ acetone, chlorophyll $a$ was quantified spectrophotometricaly without chromatographic separation and the same specific absorption coefficient was applied for both extracts (Shoaf and Lium, 1976).

The Synechococcus (WH-7803) cultures were grown in SN media (Waterbury et al., 1979) prepared from 0.75 seawater and 0.25 distilled water with added nutrients. The culture was obtained from B. Brahamsha (Scripps Institution of Oceanography, La Jolla, California). Different light climates were used: artificial light (fluorescent tubes), with 2-10 or 20-47 $\mu \mathrm{mol}$ photons $\mathrm{m}^{-2} \mathrm{~s}^{-1}$, or natural light in the laboratory, with noon irradiances between 17 and $44 \mu \mathrm{mol}$ photons $\mathrm{m}^{-2} \mathrm{~s}^{-1}$; the room temperature varied between $20^{\circ} \mathrm{C}$ and $23^{\circ} \mathrm{C}$.
Zeiss) con una lámpara de mercurio de $50 \mathrm{~W}$ y un objetivo de inmersión de 100×, empleándose en la excitación un filtro de interferencia de $480 \pm 5 \mathrm{~nm}$ (Melles-Griot), un filtro dicroico con una longitud de onda de cambio de $570 \mathrm{~nm}$ y para la emisión, un filtro de vidrio de color con una banda de transmitancia arriba de $580 \mathrm{~nm}$. Se contaron entre 200 y 300 células por muestra. Estimando la desviación estándar por la raíz cuadrada de las células contadas, el mínimo coeficiente de variación calculado fue de 6-7\%.

Los parámetros hidrográficos, nutrientes, concentración de clorofila y producción primaria se encuentran en Cervantes et al. (1996). Los nutrientes, $\mathrm{NO}_{2}, \mathrm{NO}_{3}, \mathrm{Si}(\mathrm{OH})_{4}$ y $\mathrm{PO}_{4}{ }^{3}$, fueron medidos en un autoanalizador (Technicon) de acuerdo con Whitledge et al. (1986, reporte técnico). La concentración de clorofila in situ fue medida espectrofotométricamente después de su extracción durante 24 horas a $4^{\circ} \mathrm{C}$ con acetona al $100 \%$, adicionando $10 \%$ de agua una hora antes de su medición y empleándose el coeficiente de absorción específica de Jeffrey y Humphrey (1975). La producción primaria fue medida por incorporación de ${ }^{14} \mathrm{C}$ durante incubaciones in situ (García-Mendoza y Maske, 1996).

La clorofila a de Synechococcus (WH7803) fue extraída con diferentes solventes: acetona, acetona + agua a $0.9+0.1$ (acetona al $90 \%$ ), dimetil sulfóxido (DMSO), y DMSO + acetona + agua a $0.4+0.55+0.05(\mathrm{DMSO} /$ acetona). Aquí sólo se reportan los resultados con el solvente estándar de acetona al $90 \%$ y con DMSO/acetona, ya que los otros dos solventes fueron menos eficientes. Las extracciones con acetona al $90 \%$ y DMSO/acetona se cuantificaron espectrofotométricamente sin separación cromatográfica, empleando el coeficiente de absorción específica (Shoaf y Lium, 1976). 
Ciencias Marinas, Vol. 26, No. 3, 2000

\section{RESULTS}

The data for Delfín Basin are presented in table 1 . The depth of the euphotic zone, defined by the $1 \%$ light depth, varied between 30 and $40 \mathrm{~m}$, except in September when it reached $60 \mathrm{~m}$. The surface temperature varied between $30.9^{\circ} \mathrm{C}$ in September and $19.6^{\circ} \mathrm{C}$ in December, and the salinity between 35.3 and $36.0 \mathrm{~S}$. The $\mathrm{PO}_{4}{ }^{3}$ and $\mathrm{Si}(\mathrm{OH})_{4}$ concentrations were high enough in all samples to be considered nonlimiting to phytoplankton growth. The $\mathrm{NO}_{3}$ concentration was close to zero near the surface, except in December. At the bottom of the euphotic zone, $\mathrm{NO}_{3}$ typically increased. Chlorophyll concentrations were at mesotrophic levels and in all profiles showed a maximum below the surface. The cyanobacterial concentration approximately followed the chlorophyll $a$ trend and also showed a maximum below the surface. The data from the California Current station are summarized in table 2 . The $1 \%$ light depth was shallow from May to July and increased to a maximum of $72 \mathrm{~m}$ in January. A weak, shallow thermocline was found from May to October between 15 and $20 \mathrm{~m}$, which increased to 20-30 $\mathrm{m}$ in November and January. The concentration of silicate and phosphate increased with depth and both had non-limiting concentrations near the surface, except for the phosphate concentration in May where the values above $10 \mathrm{~m}$ depth showed zero concentrations. The chlorophyll concentration and the cyanobacterial abundance showed intermediate maxima, typically at the $10 \%$ or $3.3 \%$ light level. The chlorophyll and cyanobacterial concentration was highest in July. In figures 1, 2 and 3 the cyanobacterial abundance was compared with temperature, light level, silicate and nitrate concentration, chlorophyll $a$ concentration and primary production. None of the figures indicate a significant relationship between cyanobacterial
Los cultivos de Synechococcus (WH-7803) proporcionados por B. Brahamsha (Scripps Institutution of Oceanography, La Jolla, California), crecieron en medio SN (Waterbury et al., 1979), preparado con 0.75 de agua de mar y 0.25 de agua destilada y adición de nutrientes. Los cultivos se desarrollaron bajo diferentes condiciones de luz: en luz constante de 2-10 y 20-47 $\mu \mathrm{mol}$ fotones $\mathrm{m}^{-2} \mathrm{~s}^{-1}$ y en luz natural del laboratorio durante el día entre 17 y $44 \mu \mathrm{mol}$ fotones $\mathrm{m}^{-2} \mathrm{~s}^{-1}$; la temperatura varió entre $20^{\circ} \mathrm{C}$ y $23^{\circ} \mathrm{C}$.

\section{RESULTADOS}

En la tabla 1 se muestran los datos para la Cuenca Delfín. La profundidad de la zona eufótica, definida como el $1 \%$ de $E_{s}$, varía entre 30 y $40 \mathrm{~m}$, excepto para septiembre que alcanza los $60 \mathrm{~m}$. La temperatura varía entre $30.9^{\circ} \mathrm{C}$ en septiembre y $19.6^{\circ} \mathrm{C}$ en diciembre, y la salinidad entre 35.3 y $36.0 \mathrm{~S}$. Las concentraciones de $\mathrm{PO}_{4}{ }^{3}$ y $\mathrm{Si}(\mathrm{OH})_{4}$ fueron lo suficientemente altas en todas las muestras como para no considerarlas limitantes para el crecimiento del fitoplancton. La concentración de $\mathrm{NO}_{3}$ se aproximó a cero hacia la superficie, excepto en diciembre. Hacia el fondo de la zona eufótica, la concentración de $\mathrm{NO}_{3}$ típicamente se incrementa. La concentración de clorofila $a$ se encontró dentro de los niveles mesotróficos y muestra perfiles verticales con máximos cercanos a la superficie. La concentración de las cianobacterias aproximadamente sigue el mismo comportamiento que la clorofila $a$; igualmente, sus máximos se encontraron cerca de la superficie. Los datos para la Corriente de California se resumen en la tabla 2. La profundidad de $1 \%$ de $E_{s}$ se incrementa de mayo a julio y en enero alcanza un máximo de $72 \mathrm{~m}$. Una débil termoclina se observó de mayo a octubre entre 15 y $20 \mathrm{~m}$, la cual se incrementó a 20-30 m 
Díaz and Maske: Picoplankton contribution to chlorophyll

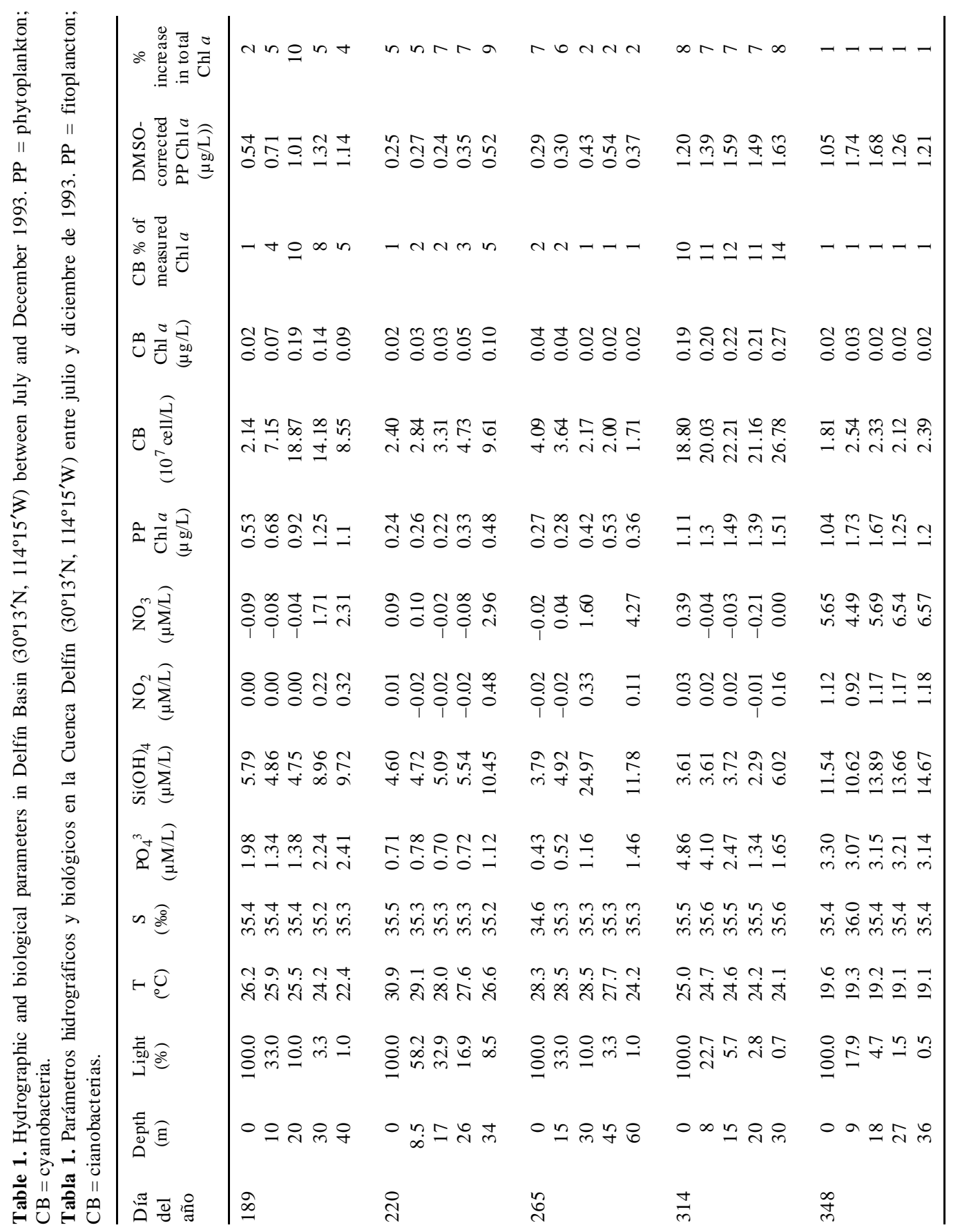


Ciencias Marinas, Vol. 26, No. 3, 2000

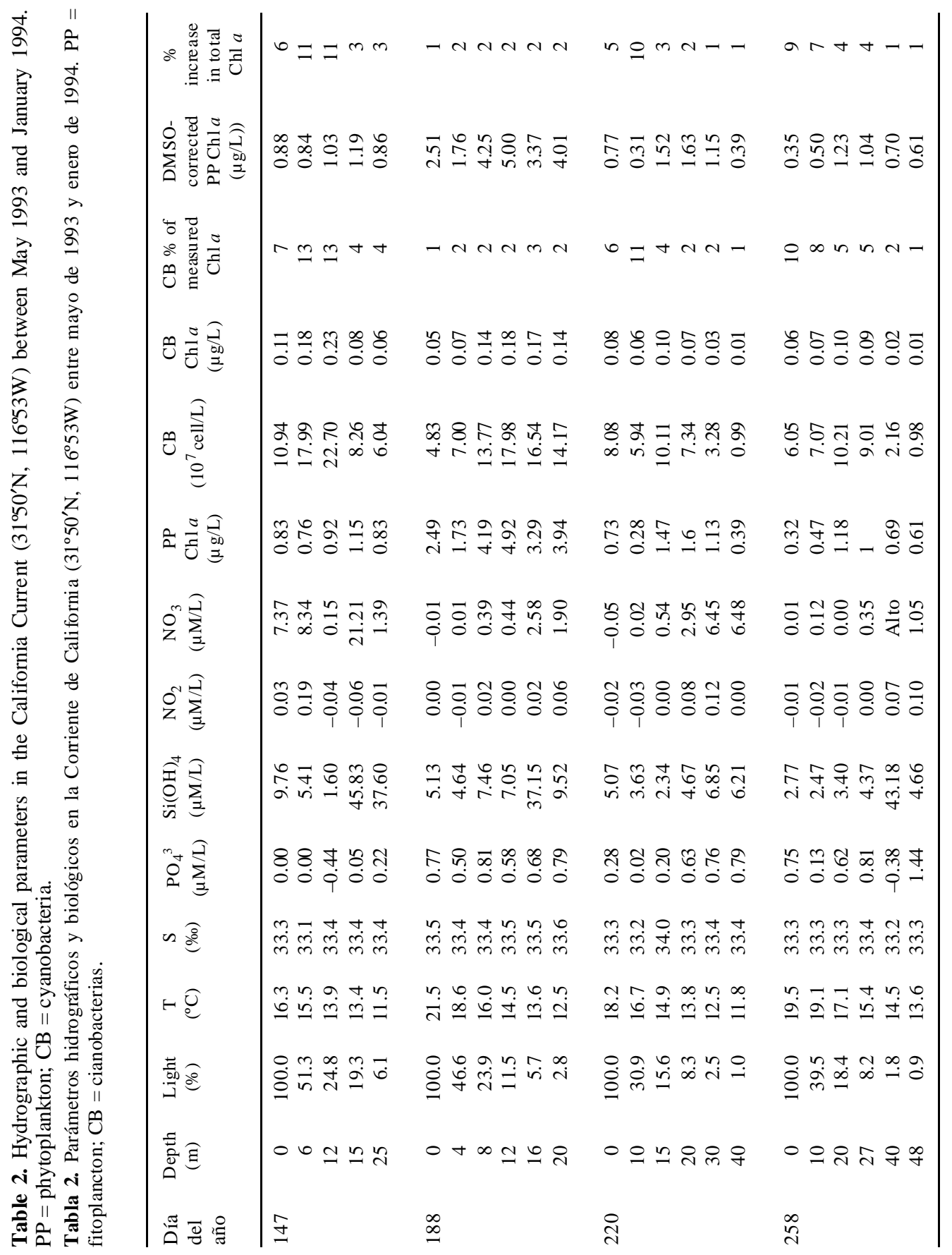


Díaz and Maske: Picoplankton contribution to chlorophyll

\begin{tabular}{|c|c|c|c|}
\hline $\begin{array}{ll}0 \\
0\end{array}$ & $000-0$ & $=\simeq+-\neg$ & $\operatorname{ran}-7$ \\
\hline 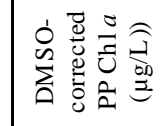 & ज̆ & તิ઼ & 웅 守 \\
\hline 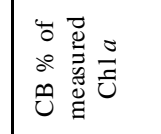 & $00--0$ & $\underline{m} \pm+n-$ & $\infty \sim N N-\longrightarrow$ \\
\hline ชี & 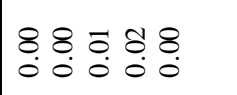 & $\begin{array}{llll}8 & 0 & 0 & 0 \\
0 & 0 & 0 & 0 \\
0 & 0 & 0 & 0\end{array}$ & 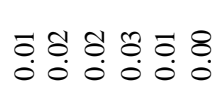 \\
\hline 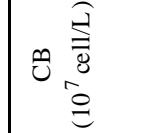 & 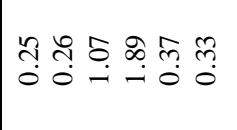 & 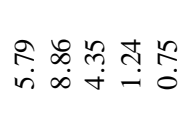 & 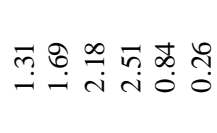 \\
\hline 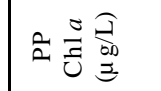 & 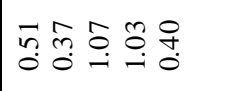 & đ่̃ & oें \\
\hline$\overbrace{z}^{m}$ & 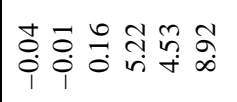 & 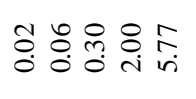 & 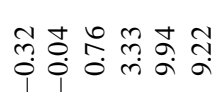 \\
\hline$\overbrace{z}^{2} \sum_{3}^{2}$ & 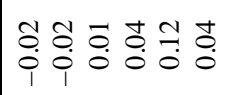 & \&: & 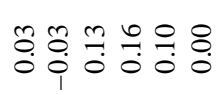 \\
\hline 产高 & 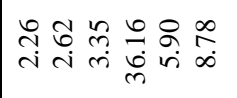 & 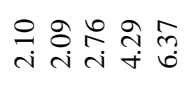 & 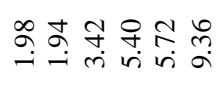 \\
\hline 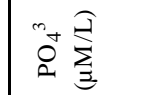 & 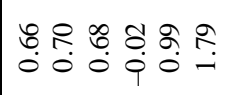 & 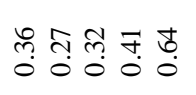 & 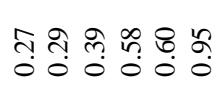 \\
\hline$n$ 的 & 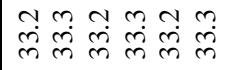 & 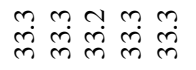 & 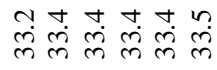 \\
\hline+0 & 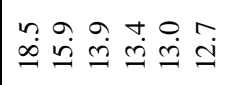 & 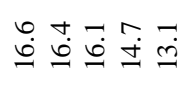 & 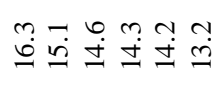 \\
\hline$\stackrel{\frac{50}{3}}{\frac{50}{3}}$ & 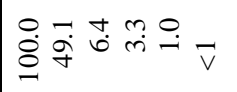 & 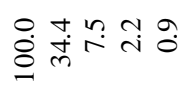 & 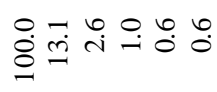 \\
\hline 苛 & 요요요 & 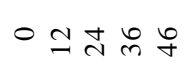 & o \\
\hline 吾 导 元 & 突 & ले & $\underset{\infty}{\infty}$ \\
\hline
\end{tabular}


Ciencias Marinas, Vol. 26, No. 3, 2000

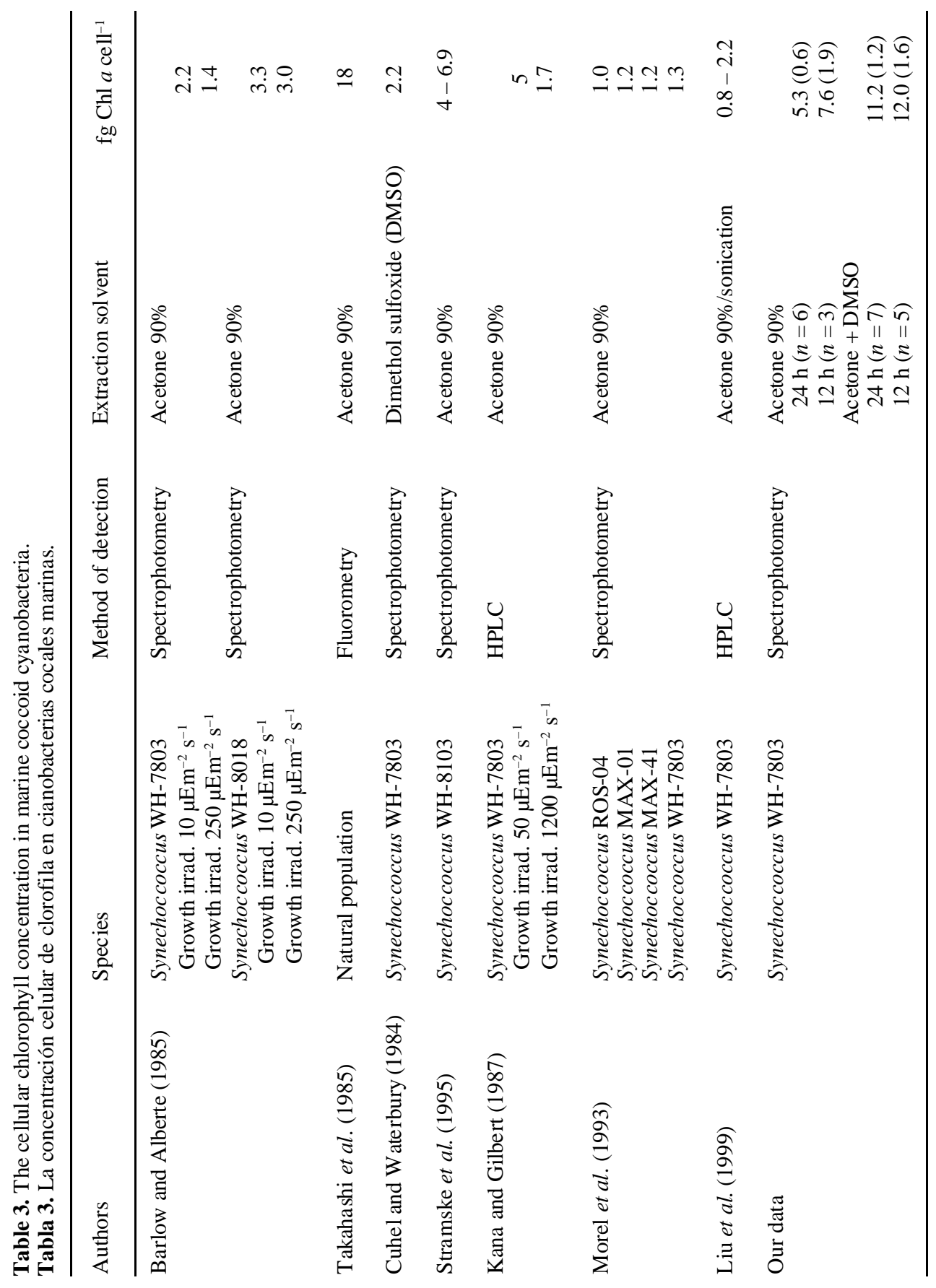


abundance and any of the above environmental parameters.

Synechococcus cultures (WH-7803) were used to test the pigment extraction efficiency of different organic solvents and extraction times. The different cultures showed consistently higher cellular chlorophyll concentration when DMSO/acetone was used for extraction than with $90 \%$ acetone. The pigment concentration was similar when the extraction period was 12 or 24 hours, but significantly lower when the extraction period was 2 hours. When the results of three different cultures are pooled then the $90 \%$ acetone extraction yielded a chlorophyll $a$ concentration of $5.3 \mathrm{fg}$ cell $^{-1}$ with the24-hour extraction and $7.6 \mathrm{fg} \mathrm{cell}^{-1}$ with the 12-hour extraction (table 3 ). The extraction with DMSO/acetone resulted in a chlorophyll $a$ concentration of $11.2 \mathrm{fg}$ cell $^{-1}$ with the 24 -hour extraction and $12.0 \mathrm{fg}$ cell $^{-1}$ with the 12 -hour extraction. The average concentrations with DMSO/acetone extraction for 12 and 24 hours were a factor of 1.87 times higher than with $90 \%$ acetone.

\section{DISCUSSION}

Coccoid cyanobacteria, specifically Synechococcus spp., are an ubiquitous part of marine phytoplankton and are found in the euphotic zone of most oceans. The coccoid cyanobacteria differ in physiology and autoecology from the eukaryotic phytoplankton, partly due to their small size and to the phycoerythrin-rich pigment system (Platt and Li, 1986). The small size of Synechococcus and the simple prokaryotic metabolism are supposed to provide Synechococcus with advantages under conditions of low nutrient concentrations. It has been shown that at nitrate concentrations between 0.5 and $3 \mu \mathrm{M}$, the growth rate of Synechococcus could reach $>2 \mathrm{~d}^{-1}$, as high as the maximum growth rate expected for eukaryotic phytoplankton during en noviembre y enero. La concentración de silicatos y fosfatos se incrementó con la profundidad y ambas concentraciones fueron no limitantes hacia la superficie, excepto para los fosfatos, cuya concentración en mayo por encima de $\operatorname{los} 10 \mathrm{~m}$ de profundidad fue de cero. Las concentraciones de clorofila $a$ y la abundancia de cianobacterias muestran máximos intermedios, típicamente en el $E_{s}$ de $10 \%$ y $3.3 \%$. Tanto la concentración de clorofila $a$ como la de cianobacterias estuvieron a su máximo punto en julio. En las figuras 1, 2 y 3 se hace una comparación de la abundancia de cianobacterias con el nivel de luz, temperatura, concentración de silicatos y nitratos, concentración de clorofila $a$ y producción primaria. Los datos en estas figuras no muestran una relación significativa entre la abundancia de cianobacterias y los parámetros ambientales.

Se emplearon cultivos de Synechococcus (WH-7803) para probar la eficiencia de extracción de pigmentos con diferentes solventes y tiempos de extracción. En los diferentes cultivos consistentemente se encontró que la concentración de clorofila celular fue más alta cuando la extracción se realizó con la mezcla de DMSO/acetona que cuando se empleó acetona al $90 \%$. Respecto al periodo de extracción, la concentración fue similar cuando la extracción se efectuó en un tiempo de 12 y 24 horas, pero fue significativamente baja cuando la extracción se realizó por 2 horas. Comparando los resultados de tres cultivos diferentes, el rendimiento de la concentración de clorofila a cuya extracción se realizó con acetona al $90 \%$ fue de $5.3 \mathrm{fg}_{\text {cél }}{ }^{-1}$ con 24 horas de extracción y $7.6 \mathrm{fg}_{\text {cé } \mathrm{l}^{-1}}$ con 12 horas de extracción (tabla 3). La concentración de clorofila $a$ extraída con DMSO/acetona fue de 11.2 y 12.0 fg cél $^{-1}$ con 24 y 12 horas de extracción, respectivamente, con un factor de 1.87 veces más alto que la extracción con acetona al $90 \%$. 

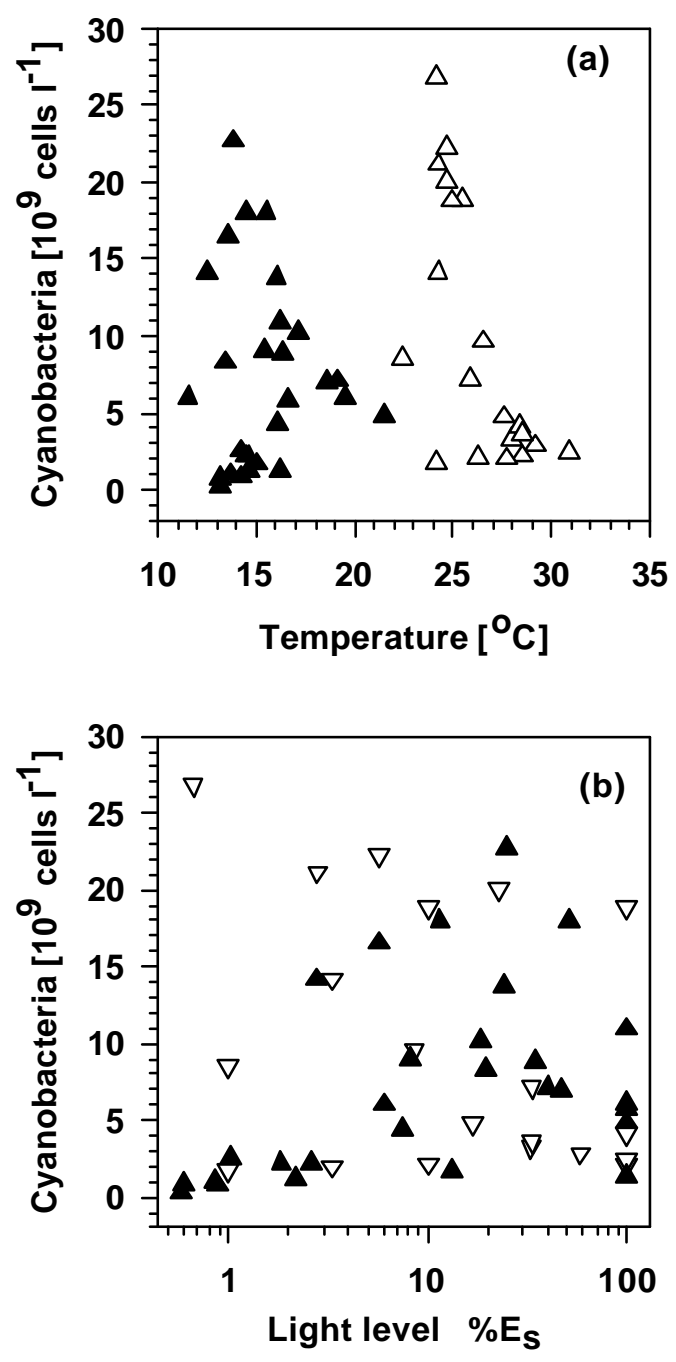

Figure 1. Abundance of cyanobacteria versus (a) temperature and (b) light level. Empty triangles indicate data from the Delfín Basin station and filled triangles from the California Current station.

Figura 1. Abundancia de cianobacterias versus (a) temperatura y (b) nivel de luz. Los triángulos blancos son datos de la estación de la Cuenca Delfín y los triángulos negros de la estación de la Corriente de California. 

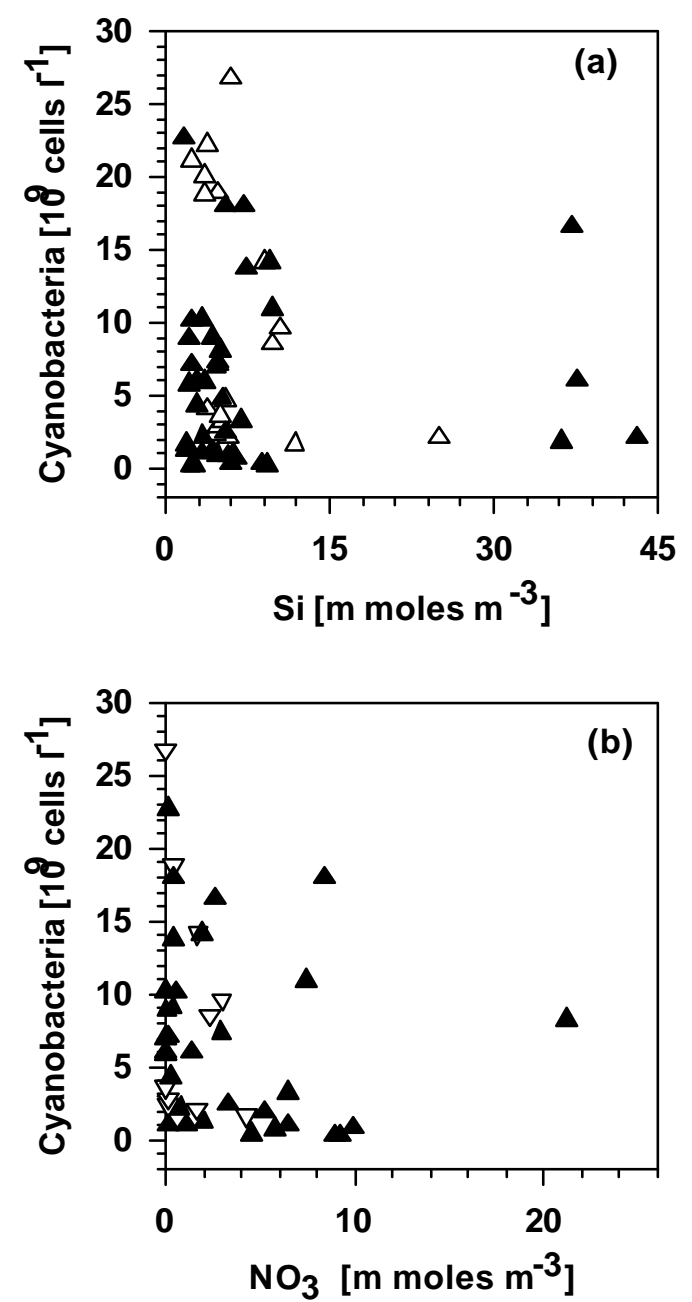

Figure 2. Abundance of cyanobacteria versus (a) in situ silicate concentration and (b) in situ nitrate concentration. Empty triangles indicate data from the Delfín Basin station and filled triangles from the California Current station.

Figura 2. Abundancia de cianobacterias versus (a) concentración de silicato in situy (b) concentración de nitrato in situ. Los triángulos blancos son datos de la estación de la Cuenca Delfín y los triángulos negros de la estación de la Corriente de California. 

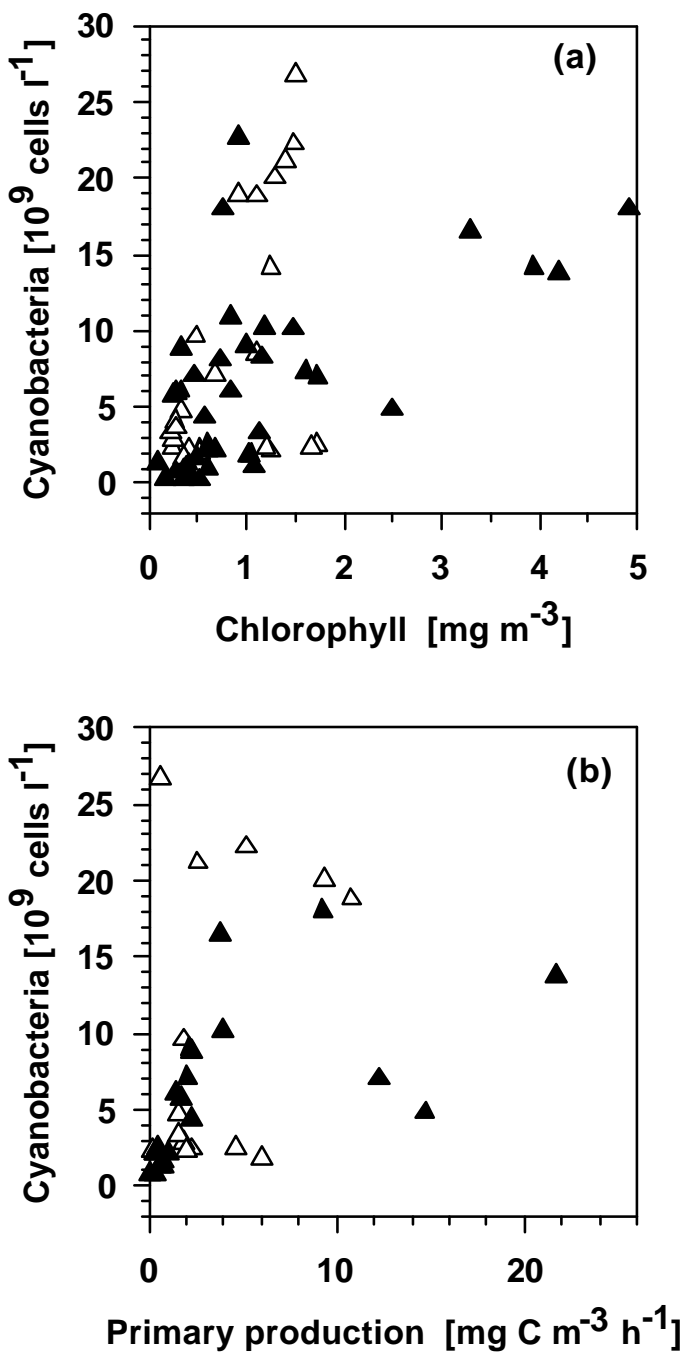

Figure 3. Abundance of cyanobacteria versus (a) chlorophyll $a$ concentration and (b) primary production. Empty triangles indicate data from the Delfín Basin station and filled triangles from the California Current station.

Figura 3. Abundancia de cianobacterias versus (a) concentración de clorofila $a$ y (b) producción primaria. Los triángulos blancos son datos de la estación de la Cuenca Delfín y los triángulos negros de la estación de la Corriente de California. 
the Monsoon period in the Arabian Sea (Liu et al., 1998). André et al. (1999) reported Synechococcus growth rates of $0.56 \mathrm{~d}^{1}$ for the equatorial Pacific. In very oligotrophic waters, another prokaryotic phytoplankton, Prochlorococcus spp., often occurs at concentrations higher than Synechococcus, albeit at low growth rates, around $0.5 \mathrm{~d}^{-1}$ (Liu et al., 1998; André et al., 1999). Li (1998) reported annually averaged oceanic Synechococcus sp. concentrations between $5 \times 10^{6}$ and $2 \times 10^{8}$ cells $\mathrm{L}^{-1}$ above $10^{\circ} \mathrm{C}$; below $10^{\circ} \mathrm{C}$, the Synechococcus concentrations tended to decrease. This author suggested that this global relationship might be related to the lower nitrate concentrations that are typical for oceanic waters above $10^{\circ} \mathrm{C}$. The concentration of coccoid cyanobacteria counted at Delfín Basin and the California Current (tables 1,2) was similar to concentrations published for other oceanic regions ( $\mathrm{Li}, 1998)$.

The accessory pigment phycoerythrin has been implied to confer a selective advantage to Synechococcus over other phytoplankton taxa at the bottom of the euphotic zone because its pigment phycoerythrin can absorb the bluegreen irradiance, which is the predominant PAR at the bottom of the euphotic zone. Recently, this argument has been extended to explain why Synechococcus strains with the additional photosynthetic pigment PUP seem to dominate in more oligotrophic waters. Wood et al. (1998) argued that the spectral quality of the photosynthetic pigments in PUP strains confers a selective advantage near the bottom of the euphotic zone in oligotrophic waters. The epifluorescent method applied by us cannot distinguish between high and low PUP strains and we are therefore limited to comparing the total Synechococcus sp. population with the chlorophyll $a$ concentration that is used here as a proxy for phytoplankton biomass. It might be expected that the specific physiological properties of cyanobacteria would result in a

\section{DISCUSIÓN}

Las cianobacterias cocales, específicamente Synechococcus spp., siempre se encuentran como parte del fitoplancton marino en la zona eufótica de los océanos. Las cianobacterias cocales difieren fisiológica y autoecológicamente del fitoplancton eucariótico, particularmente por su pequeño tamaño y sistema de pigmentos rico en ficoeritrina (Platt y Li, 1986). Su pequeño tamaño y metabolismo procariótico proporcionan a Synechococcus ventajas para su desarrollo en condiciones de bajas concentraciones de nutrientes. Se ha mostrado que en concentraciones de nitratos entre 0.5 y $3 \mu \mathrm{M}$, la velocidad de crecimiento de Synechococcus puede alcanzar hasta $>2 \mathrm{~d}^{-1}$, tan alta como la máxima velocidad de crecimiento esperada para el fitoplancton eucariótico durante el periodo monsónico en el Mar Arábico (Liu et al., 1998). André et al. (1999) reportan que Synechococcus crece a una velocidad de $0.56 \mathrm{~d}^{-1}$ en el Pacífico ecuatorial. En aguas muy oligotróficas, otro fitoplancton procariótico, Prochlorococcus spp., se encuentra en concentraciones mayores que Synechococcus, aunque con tasas de crecimiento bajas, alrededor de $0.5 \mathrm{~d}^{-1}$ (Liu et al., 1998; André et al., 1999). Li (1998) reporta un promedio anual de concentración de Synechococcus spp. oceánico de entre $5 \times 10^{6} \mathrm{y}$ $2 \times 10^{8}$ cél $\mathrm{L}^{-1}$ arriba de los $10^{\circ} \mathrm{C}$; por debajo de los $10^{\circ} \mathrm{C}$, la concentración de Synechococcus tiende a decrecer. Este autor sugiere que esta relación global puede estar relacionada con la baja concentración de nitratos que es típica en aguas oceánicas con temperaturas por arriba de los $10^{\circ} \mathrm{C}$. La concentración de cianobacterias cocales cuantificada en la Cuenca Delfín y la Corriente de California (tablas 1,2) fue similar a las concentraciones publicadas para otras regiones oceánicas (Li, 1998).

Al pigmento accesorio ficoeritrina se le ha atribuido que confiere cierta ventaja selectiva a 
Ciencias Marinas, Vol. 26, No. 3, 2000

characteristic pattern of the cell abundance and environmental conditions, but no obvious trend was found in figures 1,2 and 3 . The lackof a relationship might be explained by the top-down control by grazing pressure. There may be a fundamental difference in the mechanisms of biomass control between coccoid cyanobacteria and nanophytoplankton in the euphotic zone of oceanic waters above $10^{\circ} \mathrm{C}$, as indicated by the relative constancy of coccoid cyanobacterial abundance (Li, 1998), in contrast to nanophytoplankton with its abundance varying several orders of magnitude. For the interpretation of Synechococcus abundance (tables 1,2), it has to be considered that the Synechococcus abundance can show a daily oscillation, with a maximum 1.5 times higher than the minimum cell abundance around noon when our samples were normally taken. This oscillation is due to the phasing of cell reproduction (Liu et al., 1998; Vaulot and Marie, 1999).

The amount of chlorophyll that is associated with cyanobacterial cells in the field samples can be calculated from the cellular chlorophyll a concentration of Synechococcus cultures after extraction with $90 \%$ acetone (table 3) and the cyanobacterial abundance in situ (tables 1,2). The cellular chlorophyll a concentration measured by us was fairly constant, but significantly higher than most published cellular chlorophyll $a$ concentrations (table 3). This can be explained by the low growth irradiance used in our cultures (Kana and Gilbert, 1987). From the published data (table 3), 1 fg Chl $a$ per coccoid cyanobacterial cell was chosen as being representative for natural populations. In tables 1 and 2 the in situ chlorophyll $a$ concentration that originated from cyanobacteria was calculated by multiplying the cellular abundance by $1 \mathrm{fg} \mathrm{Chl} a$ cell $^{-1}$. If $\varepsilon$ is the extraction efficiency, $C_{m}$ is the measured chlorophyll $a$ concentration, $C_{t}$ the true concentration, $C_{e}$ the true eukaryote and $C_{p}$ the
Synechococcus sobre otros taxa de fitoplancton hacia el fondo de la zona eufótica, debido a que el pigmento ficoeritrina puede absorber la luz verde-azul, que es la PAR predominante hacia el fondo de la zona eufótica. Recientemente este argumento se ha utilizado para explicar por qué aquellas cepas de Synechococcus con el pigmento fotosintético adicional PUP parecen ser más dominantes en aguas oligotróficas. Wood et al. (1998) argumentan que la calidad espectral de los pigmentos fotosintéticos en cepas con PUP confieren una ventaja selectiva cerca del fondo de la zona eufótica en aguas oligotróficas. El método de epifluorescencia empleado aquí no permite distinguir entre las cepas con alta y baja concentración de PUP y, por consiguiente, nos vimos limitados a comparar la población total de Synechococcus spp. con la concentración de clorofila $a$ que se utilizó aquí como un indicador de la biomasa de fitoplancton. Se esperaría que por sus propiedades fisiológicas específicas las cianobacterias muestren un patrón característico de abundancia celular y de propiedades ambientales. Sin embargo, no se encuentra ninguna tendencia obvia en las figuras 1, 2 y 3. La carencia de relación puede explicarse por el control ecológico de arriba hacia abajo en la cadena trófica (top-down) por presión de pastoreo. Podría haber una diferencia fundamental en los mecanismos de control de la biomasa entre las cianobacterias cocales y el nanofitoplancton de la zona eufótica en aguas oceánicas con temperaturas arriba de $10^{\circ} \mathrm{C}$, como lo indica la relativamente constante abundancia de cianobacterias cocales ( $\mathrm{Li}, 1998)$ en contraste con el nanofitoplancton cuya abundancia puede cambiar en varios órdenes de magnitud. Para la interpretación de la abundancia de Synechococcus (tablas 1, 2), se ha considerado que dicha abundancia puede mostrar una oscilación diaria con un máximo de 1.5 veces más alta que la mínima abundancia celular alrededor del mediodía, cuando normalmente 
true prokaryote chlorophyll a concentration, then

$$
\begin{aligned}
& C_{m}=C_{e}+C_{p} * \varepsilon \\
& C_{t}=C_{e}+C_{p} \\
& C_{t}=C_{m}+C_{p} *(1-\varepsilon)
\end{aligned}
$$

$C_{p}$ was calculated by multiplying the cell abundance with 1 fg Chl $a$ cell $^{-1}, \varepsilon=1 / 1.87$; $C_{p} / C_{t}$, the cyanobacteria chlorophyll $a$ to total chlorophyll $a$ concentration, indicates the relative contribution of cyanobacteria to the phytoplankton biomass. The contribution ranged from $1 \%$ to $19 \%$ in Delfín Basin and from $0.5 \%$ to $23 \%$ in the California Current. The median of the cyanobacterial contribution was $10 \%$ in Delfín Basin and $4 \%$ in the California Current. Vernet et al. (1990) reported that Synechococcus contributed between $4 \%$ and $15 \%$ to the total in situ chlorophyll $a$ at a station in the California Current. Because the cyanobacteria in situ samples were taken around noon, at a time when cell concentrations are typically at a minimum, the contribution of coccoid cyanobacteria to total chlorophyll $a$ could have been higher during the rest of the day. It can be concluded that the relative contribution of coccoid cyanobacteria to the primary producers in the two sampling locations was variable and significant. Obviously the above values are directly proportional to the cellular amount of chlorophyll $a$ assumed for natural populations of cyanobacteria.

Our comparison of different extraction solvents showed that DMSO/acetone was 1.87 times more efficient to extract chlorophyll in Synechococcus cultures (table 3). The use of $90 \%$ acetone for the extraction of marine phytoplankton pigments has always been a compromise: a solvent is used of relatively low toxicity that does not require additional physical breakage of the cells, but that still provides a reasonable extraction efficiency se recolectaron nuestras muestras. Esta oscilación es debida a la fase de reproducción celular (Liu et al., 1998; Vaulot y Marie, 1999).

La cantidad de clorofila asociada con las células de cianobacterias en las muestras de campo se calculó de la concentración celular de clorofila $a$ de los cultivos de Synechococcus después de la extracción con acetona al $90 \%$ (tabla 3) y la abundancia de cianobacterias in situ (tablas 1, 2). La concentración celular de clorofila $a$ medida por nosotros fue poco variable, pero más alta que la concentración celular de clorofila $a$ publicada (tabla 3 ). Esto puede explicarse por la baja irradiancia empleada en nuestros cultivos (Kana y Gilbert, 1987). De los datos publicados (tabla 3), $1 \mathrm{fg}$ Chl $a$ por célula de cianobacteria cocal se consideró como representativo de las poblaciones naturales. En las tablas 1 y 2 la concentración in situ de clorofila $a$ originada de las cianobacterias se calculó multiplicando la abundancia celular por $1 \mathrm{fg}$ Chl $a$ cél $^{1}$. La razón de la clorofila $a$ de las cianobacterias a la concentración de clorofila $a$ total está calculada de la siguiente manera: si $\varepsilon$ es la eficiencia de extracción, $C_{m}$ es la concentración de clorofila $a$ medida, $C_{t}$ la concentración real, $C_{e}$ la concentración de la clorofila $a$ de los eucariotes y $C_{p}$ la concentración de los procariotes, entonces

$$
\begin{aligned}
& C_{m}=C_{e}+C_{p} * \varepsilon \\
& C_{t}=C_{e}+C_{p} \\
& C_{t}=C_{m}+C_{p} *(1-\varepsilon)
\end{aligned}
$$

$C_{p}$ se puede calcular por multiplicación de la concentración celular con $1 \mathrm{fg}$ Chl $a$ cél $^{-1}$, $\varepsilon=1 / 1.87 ; C_{p} / C_{t}$ es la fracción de la clorofila $a$ de las cianobacterias entre la clorofila $a$ total e indica la contribución relativa de las cianobacterias a la biomasa de fitoplancton. La contribución de las cianobacterias varía entre $1 \%$ y $19 \%$ en la Cuenca Delfín y entre $0.5 \%$ y $23 \%$ en la Corriente de California. La contribución 
Ciencias Marinas, Vol. 26, No. 3, 2000

with diatom cells, the dominant marine phytoplankton phylum in mesotrophic waters. Recently, Wright et al. (1997) reviewed the pigment extraction procedures for marine phytoplankton and did some comparative measurements with phytoplankton cultures, that also included Synechococcus. They found relatively low extraction efficiencies with $90 \%$ acetone and they recommended the use of methanol with sonication for routine pigment extractions. Among their different extraction solvents, dimethylformamide (DMF) with sonication performed best but was not recommended for routine measurements because of the toxicity of DMF. In their comparison, DMSO was used to presoak the sample filters for 24 hours and then extract the filters by grinding with acetone. This method yielded better results than soaking with $90 \%$ acetone, but significantly lower concentrations than sonication with methanol. We also found that $100 \%$ DMSO did not yield as high a concentration as DMSO/acetone and this may explain the unsatisfactory results obtained by Wright $e t$ al. (1997). Nevertheless, we have no information on the relative performance of our extraction method with DMSO/acetone compared to the DMF/sonication extraction. Latasa and Bidigare (1998) compared the extraction efficiency of DMF, methanol and acetone with natural phytoplankton from the Arabian Sea and found no significant difference in extraction efficiency between the solvents, despite high cyanobacterial concentrations in samples as indicated by the zeaxanthin concentrations. They sonicated their samples and that explains why they found no difference in extraction efficiency between solvents (cf. Wright et al., 1997).

From equation 1, the expected increase in total chlorophyll concentration with total cyanobacteria extraction can be calculated:

$$
C_{t} / C_{m}=1+\left(C_{p} *(1-\varepsilon)\right) / C_{m}
$$

mediana de las cianobacterias fue de $10 \%$ en la Cuenca Delfín y $4 \%$ en la Corriente de California. Vernet et al. (1990) encontraron que Synechococcus contribuye entre $4 \%$ y $15 \%$ a la clorofila $a$ in situ. Ya que nuestras muestras de cianobacterias in situfueron tomadas alrededor del mediodía, que es cuando la concentración de células tiende típicamente hacia un mínimo, la contribución de las cianobacterias cocales a la clorofila $a$ total podría ser más alta durante el resto del día. Puede concluirse que la contribución relativa de las cianobacterias cocales a la producción primaria en las dos localidades de muestreo fue variable y significativamente alta.

Nuestra comparación con los diferentes solventes de extracción muestra que la mezcla de DMSO/acetona es 1.87 veces más eficiente para la extracción de clorofila en los cultivos de Synechococcus (tabla 3). Sin embargo, el uso de acetona al $90 \%$ sin tratamiento físico para facilitar la extracción de los pigmentos de fitoplancton marino tiene sus ventajas: se usa un solvente de baja toxicidad que no requiere de previo rompimiento de las células pero que, a la vez, también proporciona una buena eficiencia de extracción con células de diatomeas, que representan el phylum dominante del fitoplancton marino en aguas mesotróficas. Wright et al. (1997) llevaron a cabo una revisión de los procedimientos de extracción de pigmentos de fitoplancton marino y algunas mediciones comparativas con cultivos de fitoplancton que incluyen Synechococcus; encontraron una baja eficiencia de extracción con acetona al $90 \%$ y recomiendan el uso del metanol, además de la aplicación del ultrasonido, para las mediciones rutinarias de pigmentos. Entre los diferentes solventes de extracción, la dimetil formamida (DMF) combinado con el ultrasonido resultó mejor, pero no es recomendable en las mediciones rutinarias dada la toxicidad del mismo. En esta comparación, el DMSO se usó para la extracción durante 24 horas; posteriormente, 
The calculated median increase in percent $\left(100 *\left(C_{t} / C_{m}-1\right)\right)$ would be $5 \%$ in Delfín Basin and $2 \%$ in the California Current (tables1,2). The real increase in chlorophyll concentration when physical disruption, sonication or DMSO/acetone solvent are used could be higher because other phytoplankton phyla might also show increased extraction efficiency. The results of Wright et al. (1997) show that the chlorophyll concentrations of other phytoplankton taxa are also typically underestimated with the $90 \%$ acetone extraction. The results indicate that the choice of $90 \%$ acetone without additional physical disruption by sonication can produce a significant but variable underestimation of the in situ chlorophyll concentration.

\section{ACKNOWLEDGEMENTS}

We thank María Vernet for her assistance; B. Brahamsha (SIO, La Jolla) for providing the WH-7803 cultures; R. Cajal (UABC, Ensenada) and R. Cervantes (CICIMAR, La Paz) for their help during the sampling and analysis of the data; and M. Díaz and J. Sidon for their help during the field work.

\section{REFERENCES}

André, J.M., Navarette C., Blanchot J. and Radenac, M.H. (1999). Picophytoplankton dynamics in the equatorial Pacific: Growth and grazing rates from cytometric counts. J. Geophys. Res., 104: 3369-3380.

Barlow, R.G. and Alberte, R.S. (1985). Photosynthetic characteristics of phycoerythrincontaining marine Synechococcus spp. Mar. Biol., 86: 63-74.

Booth, B.C. (1987). The use of fluorescence for analyzing oceanic phytoplankton communities. Bot. Mar., 30: 101-108.

Cervantes, D.R., Maske, R.H. y García, M.E. (1996). Datos planctónicos ópticos e hidrográficos del Golfo de California y Corriente de California los filtros fueron homogeneizados con acetona. Por este método el rendimiento fue mejor que la extracción con acetona al $90 \%$, pero la concentración fue significativamente más baja que la aplicación del ultrasonido con metanol. Latasa y Bidigare (1998) compararon la eficiencia de la extracción de clorofila $a$ de muestras del Mar Árabe con DMF, metanol y acetona utilizando ultrasonido y no encontraron diferencias significativas. Nuestros resultados muestran que el DMSO al $100 \%$ no tuvo un rendimiento en la concentración tan alto como la mezcla de DMSO/acetona, lo que posiblemente explica los resultados poco satisfactorios de Wright et al. (1997). No obstante, nosotros no podemos informar respecto a la comparación relativa entre el método empleado por nosotros con DMSO/acetona y aquel que utiliza la extracción con DMF/ultrasonido.

De la ecuación 1 se puede derivar el aumento relativo en la concentración de clorofila $a$ in situ con la extracción completa de las cianobacterias:

$$
C_{t} / C_{m}=1+\left(C_{p} *(1-\varepsilon)\right) / C_{m}
$$

El mediano del aumento en por ciento $\left(100 *\left(C_{t} / C_{m}-1\right)\right)$ sería de $5 \%$ para la Cuenca Delfín y $2 \%$ para la Corriente de California (tablas 1,2). Estos cálculos son sólo considerando el error de extracción debido a las cianobacterias cocales; el aumento real podría ser más alto porque otros phyla de fitoplancton también podrían mostrar más clorofila $a$ extraída con DMSO/acetona. Los resultados de Wright et al. (1997) muestran que las concentraciones de clorofila de otros taxa de fitoplancton también son típicamente subestimadas con la extracción con acetona al $90 \%$. Nuestros resultados indican que el uso de acetona al $90 \%$ sin la adicional ruptura mecánica de las células puede producir una significativa pero variable subestimación de la concentración de clorofila in situ. 
Ciencias Marinas, Vol. 26, No. 3, 2000

(1992-1995). Comunicaciones Acádemicas, Ser. Ecología, CICESE, 289 pp.

Cuhel, R.L. and Waterbury, J.B. (1984). Biochemical composition and short-term nutrient incorporation patterns in a unicellular marine cyanobacterium Synechococcus (WH7803). Limnol. Oceanogr., 29: 370-374.

García-Mendoza, E. and Maske, H. (1996). The relationship of solar-stimulated natural fluorescence and primary productivity in Mexican Pacific waters. Limnol. Oceanogr., 4(18): 1697-1710.

Ikeya, T., Ohki, K., Takahashi, M. and Fujita, Y. (1994). Photosynthetic characteristics of marine Synechococcus spp. with special reference to light environments near the bottom of the euphotic zone of the open ocean. Mar. Biol., 118: 215-221.

Iturriaga, R. and Mitchell, B.G. (1986). Chrococcoid cyanobacteria: A significant component in the food web dynamics of the open ocean. Mar. Ecol. Prog. Ser., 28: 291-297.

Jeffrey, S.W. and Humphrey, G.F. (1975). New spectrophotometric equations for determining chlorophylls $a, b$ and $c 1$ and $c 2$ in higher plants, algae and natural phytoplankton. Biochem. Physiol. Pflanzen, 167: 191-194.

Kana, T.M. and Gilbert, P.M. (1987). Effect of irradiances up to $2000 \mu \mathrm{E} \mathrm{m}^{-2} \mathrm{~s}^{-1}$ on marine Synechococcus WH7803-I. Growth, pigmentation, and cell composition. Deep-Sea Res., 34: 479-495.

Latasa, M. and Bidigare, R.R. (1998). A comparison of phytoplankton populations of the Arabian Sea during the spring intermonsoon and southwest monsoon of 1995 as described by HPLC-analyzed pigments. Deep-Sea Res. II, 45: 2133-2170.

Li, W.K.W. (1998). Annual average abundance of heterotrophic bacteria and Synechococcus in surface ocean waters. Limnol. Oceanogr., 43: 1746-1753.

Liu, H., Campbell, L., Landry, M.R., Nolla, H.A., Brown, S.L. and Constantinuou, J. (1998). Prochlorococcus and Synchecoccus growth rates and contributions to production in the Arabian Sea during the 1995 southwest and northeast monsoons. Deep-Sea Res. II, 45: 2327-2352.

\section{AGRADECIMIENTOS}

Agradecemos a María Vernet la asesoría brindada; a B. Brahamsha (SIO, La Jolla) los cultivos de WH-7803 proporcionados; a R. Cajal (UABC, Ensenada) el apoyo y asistencia en el manejo del método de epifluorescencia; a R. Cervantes (CICIMAR, La Paz) la ayuda brindada durante el desarrollo del trabajo; y a M. Díaz y J. Sidon su ayuda en los muestreos de campo.

Traducido al español por los autores.

Liu, H., Campbell, L., Bidigare, R.R., Laws, E., Landry, M.R. and Campbell, L. (1999). Cell cycle and physiological characteristics of Synchecoccus (WH7803) in chemostat culture. Mar. Ecol. Prog. Ser., 189: 17-25.

Morel, A., Ahn, Y.-H., Partensky, F., Vaulot, D. and Claustre, H. (1993). Prochlorococcus and Synechococcus: A comparative study of their optical properties in relation to their size and pigmentation. J. Mar. Res., 51: 617-649.

Platt, T. and Li, W.K.W. (1986). Photosynthetic picoplankton. Can. Bull. Fish. Aquat. Sci., 214 $583 \mathrm{pp}$.

Shoaf, W.T. and Lium, B.W. (1976). Improved extraction of chlorophyll $a$ and $b$ from algae using dimethyl sulfoxide. Limnol. Oceanogr., 21: 926-928.

Smith, V.H. (1986). Light and nutrient effects on the relative biomass of blue-green algae in lake phytoplankton. Can. J. Fish Aquat. Sci., 43: 148-153.

Stramske, D., Shalapyonok, A. and Reynolds, R.A. (1995). Optical characterization of the oceanic unicellular cyanobacterium Synechococcus grown under a day-night cycle in natural irradiance. J. Geophys. Res., 100: 13295-13307.

Takahashi, M., Kikuchi, K. and Hara, Y. (1985). Importance of picocyanobacteria biomass (unicellular, blue-green algae) in the phytoplankton population of the coastal waters off Japan. Mar. Biol., 89: 63-69. 
Díaz and Maske: Picoplankton contribution to chlorophyll

Vaulot, D. and Marie, D. (1999). Diel variability of photosynthetic picoplankton in the equatorial Pacific. J. Geophys. Res., 104: 3297-3310.

Vernet, M., Mitchell, B. and Holm-Hansen, O. (1990). Adaptation of Synechococcus in situ determined by variability in intracellular phycoerytrin -543 at a coastal station off the Southern California coast. Mar. Ecol. Prog. Ser., 63: 9-16.

Waterbury, J.B., Watson, S.W., Guillard, R.R.L. and Brand, L.E. (1979). Widespread occurrence of a unicellular, marine, planktonic cyanobacterium. Nature, 277: 293-294.

Whitledge, T.E., Veidt, D.H., Malloy, S.C., Patton, C.J. and Wirick, C.D. (1986). Automated nutrient analyses in seawater.
Brookhaven National Lab., Technical Rep. BNL38990.

Wood, A.M., Phinney, D.A. and Yentsch, C.S. (1998). Water column transparency and the distribution of spectrally distinct forms of phycoerythrin-containing organisms. Mar. Ecol. Prog. Ser., 162: 25-31.

Wright, S.W., Jeffrey, S.W. and Mantoura, R.F.C. (1997). Evaluation of methods and solvents for pigment extraction. In: S.W. Jeffrey, R.F.C. Mantoura and S.W. Wright (eds.), Phytoplankton Pigment in Oceanography. UNESCO, Paris, pp. 261-282.

Wyman, M., Gregory, R.P.F. and Carr, N.G. (1985). Novel role for phycoerythrin in a marine cyanobacterium Synechococcus strain DC2. Science, 230: 818-820. 